\title{
Pengaruh Penggunaan Biochar Berbahan Sufmuti (Chromolaena Odorata) dan Teh Kompos Berbahan Ekskreta Ayam terhadap Kandungan Nutrien Rumput Odot (Pennisetum Purpureum Cv. Mott)
}

\author{
Irmalis B. Watu ${ }^{\mathrm{a}}$, Oktovianus R. Nahak \\ ${ }^{a}$ Fakultas Pertanian, Universitas Timor, Kefamenanu, TTU - NTT, 85613, Indonesia, email: lanaikofi@ gmail.com \\ ${ }^{b}$ Fakultas Pertanian, Universitas Timor, Kefamenanu, TTU - NTT, 85613, Indonesia, email: oktovianusrafael@yahoo.co.id
}

\section{Article Info}

\section{Article history:}

Received 23 Juni 2021

Received in revised form 11 Juli 202

Accepted 30 Juli 2021

https://doi.org/10.32938/ja.v6i3.1400

\section{Keywords:}

Biochar

Teh Kompos

Rumput Odot

\section{Abstrak}

Penelitian dilaksanakan pada 2 lokasi yaitu proses budidaya berlangsung di Kebun Percobaan milik Program Studi Peternakan, Fakultas Pertanian, Universitas Timor, sedangkan analisis kandungan nutrien dilaksanakan pada Laboratorium kimia Pakan, Universitas Nusa Cendana Kupang. Penelitian berlangsung selama satu periode (60 HST) dan dimulai pada bulan bulan Mei sampai akhir Juni 2020. Tujuan penelitian untuk mengetahui level terbaik penggunaan biochar pada nilai nutrien rumput odot, untuk mengetahui dosis terbaik penggunaan teh kompos pada nilai nutrien rumput odot, dan untuk mengetahui apakah terjadi interaksi pada pemberian biochar dan teh kompos. Penelitian ini merupakan penelitian eksperimen dengan menggunakan Rancangan Acak Lengkap (RAL) pola faktorial 3x3 yang

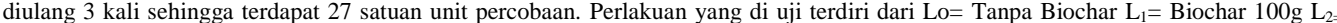
Biochar 200g dan Do= Tanpa Teh Kompos $\mathrm{D}_{1=}$ Dosis $150 \mathrm{ml} \mathrm{D}_{2=}$ Dosis $300 \mathrm{ml}$. Variabel yang di amati dalam penelitian ini adalah Kandungan Bahan Kering (BK), Kandungan Bahan Organik (BO), Kandungan Serat Kasar (SK). (1) Hasil penelitian menunjukkan pemberial level biochar dapat memberikan pengaruh nyata terhadap produksi bahan kering dan serat kasar yang dihasilkan, level biocha $200 \mathrm{~g}\left(\mathrm{~L}_{2}\right)$ menghasilkan produksi bahan kering tertinggi yaitu 94,65\% dan kandungan serat kasar yang terendah sebesar 24, 39\%. (2). Pemberian dosis teh kompos memberikan pengaruh yang nyata terhadap bahan organik rumput odot. Dosis teh kompos 300ml/tanaman $\left(D_{2}\right)$ memberikan hasil terhadap kandungan bahan organik rumput odot sebesar $79,27 \%$. (3). Tidak terjadi interaksi antara faktor pada semua variabel pengamatan.

\section{Pendahuluan}

Budidaya hijauan makanan ternak merupakan aspek penting dalam upaya mencukupi kebutuhan ternak sehingga harus tetap berkelanjutan pada suatu usaha peternakan. Hijauan pakan yang baik tentunya harus memperhatikan aspek kualitas, kuantitas serta keberlanjutannya. Budidaya pakan ternak di lahan kering memiliki tantangan tersendiri mengingat karakteristik lahan kering seperti intensitas hujan dan kelembaban yang rendah serta evapotranspirasi, suhu lingkungan yang tinggi menyebabkan tanaman sulit untuk berproduksi dan menghasilkan kualitas nutrien yang baik. Selain itu dinamika musim di lahan kering juga sangat mempengaruhi fluktuasi terhadap kualitas nutrien hijauan yang ada. Rumput odot juga merupakan pakan hijauan bernutrisi tinggi dan sangat baik untuk dikonsumsi oleh ternak.

Rumput odot merupakan jenis rumput unggul yang mempunyai produktivitas dan kandungan nutrien yang cukup tinggi seperti protein kasar yang mencapai 12-14\% (Hartanto, 2008). Rumput ini memiliki ukuran yang lebih kecil dari rumput gajah, dapat tumbuh pada berbagai macam tanah dansangat responsif terhadap pemupukan. Tumbuh berumpun dengan perakaran serabut dan terus menghasilkan anakan apabila dipangkas secara teratur. Kualitas nutrien rumput odot juga sangat dipengaruhi oleh teknik budidaya yang diterapkan. Selain itu juga penerapan aplikasi teknologi seperti pemupukan juga ikut mempengaruhi antara lain tahan kering dan hanya dapat di propogasi melalui metode vegetatif, zat gizi yang cukup tinggi serta memiliki palatabilitas yang tinggi bagi ternak (Lasamadi et al., 2013).

Semak bunga putih atau dalam bahasa dawan sufmuti merupakan salah satu tanaman gulma yang sangat invasif di pulau Timor sehingga berpotensi sebagai sumber bahan organik (pupuk hijauan) dan makanan ternak. Untuk memenuhi ketersediaan yang cukup dan kontinyu serta nutrien yang tinggi bagi tanaman maka dilakukan pemupukan. Pemupukan bertujuan untuk menyediakan unsur hara yang dibutuhkan oleh tanaman dalam setiap periode tumbuhnya. Peningkatan produktivitas pada tanaman rumput dapat diusahakan dengan pengelolaan tanah yang baik, pemupukan dan pemeliharaan tanaman. Adanya pemupukan kesuburan lahan dapat meningkatkan produktivitas serta nilai nutrien tanaman rumput yang dibudidayakan (Murbandon, 1999).

Penggunaan paket teknologi dengan pemberian biochar untuk tanaman dan aplikasi teh kompos pada tanaman merupakan salah satu solusi dalam menyediakan hara yang dibutuhkan untuk mendukung pertumbuhan tanaman. Kompos dan teknologi pengomposan berkembang hampir bersamaan dengan perkembangan pertanian. Kualitas teh kompos sangat ditentukan oleh kualitas kompos sebagai bahan bakunya dan proses pengomposannya. Pengomposan adalah proses penguraian bahan organik secara biologis yang difasilitasi oleh mikroorganisme. Kompos sebagai produk pengomposan perlu diukur kualitasnya. Indikator utama kualitas kompos adalah kematangan dan stabilitas kompos (Radovich et al., 2011). Biochar atau yang lebih dikenal sebagai arang merupakan materi padat yang terbentuk dari karbonisasi biomasa. Biochar dapat ditambahkan kedalam tanah dengan tujuan untuk meningkatkan fungsi tanah dan mengurangi emisi dari biomasa yang secara alami terurai menjadi gas rumah kaca. Biochar juga mempunyai fungsi untuk mengikat karbon cukup besar. Pupuk kandang yang digunakan dalam penelitian ini adalah ekskreta ayam, lamtoro yang diolah menjadi pupuk cair atau teh kompos dan biochar dari arang sufmuti. Penggunaan pupuk kandang dapat menambah hara, merubah keadaan fisik dan biologi tanah. Berdasarkan hal di atas maka perlu diketahui kualitas nutrien rumput odot dengan pemupukan biochar dan teh kompos sehingga peneliti tertarik dengan mengambil judul penelitian: "Pengaruh Penggunaan Biochar Berbahan Sufmut (Chromolaena odorata) dan Teh Kompos Berbahan Ekskreta Ayam Terhadap Kandungan Nutrien Rumput Odot (Pennisetum purpureum $C v$. Mott.).

Teh kompos dan biochar merupakan salah satu alternatif dalam penerapan teknologi pertanian organik yang berwawasan lingkungan dan keberlanjutan. Teh kompos mengandung unsur-unsur hara yang dibutuhkan oleh tanaman dan ekosistem tanah untuk meningkatkan kualitas nutrisi dari tanaman. Oleh karena itu, perlu adanya upaya peningkatan penggunaan biochar dan teh kompos yang dikaitkan dengan penggunaan pupuk organik berupa pupuk kandang.

\section{METODE PENELITIAN}

Penelitian dilaksanakan pada 2 lokasi yaitu pada proses budidaya berlangsung di kebun Pecobaan milik Program Studi Peternakan, Fakultas Pertanian, Universitas Timor. Sedangkan analisis nutrisi berlangsung di Laboratorium kimia Pakan, Universitas Nusa Cendana Kupang. Penelitian berlangsung selama satu periode (60 HST) dan dimulai pada Mei sampai akhir Juli 2020

Peralatan yangdigunakan terdiri dari: alat ukur seperti meter dan peralatan pendukung yaitu alat bercocok tanam seperti: pacul, parang, ember dan gayung, blender, timbangan analitik, pengayak tanah, gunting dan alat tulis.

Bahan yangdigunakan seperti: Polibag kapasitas $5 \mathrm{~kg}$, stek rumput odot $15 \mathrm{~cm}$ setiap pols, sufmuti untuk pembuatan biochar dan lamtoro, dedak padi, feses ayam untuk pembuatan teh kompos dan tanah coklat (Entisol).

Penelitian ini merupakan penelitian eksperimen dengan menggunakan Rancangan Acak Lengkap (RAL) pola faktorial 3x3 yang masing-masing perlakuan diulang sebanyak 2 kali.

\begin{tabular}{|c|c|}
\hline & \\
\hline I & $=\mathrm{Bi}$ \\
\hline L & $\begin{array}{l}=\mathrm{Bio} \\
=\mathrm{Bio}\end{array}$ \\
\hline
\end{tabular}

Faktor II. Dosis Teh Kompos

$\mathrm{D}_{0} \quad=$ Tanpa Teh Kompos

$\mathrm{D}_{1} \quad=$ Dosis $150 \mathrm{ml}$

$\mathrm{D}_{2} \quad=$ Dosis $300 \mathrm{ml}$

Dari kedua faktor diatas dihasilkan 9 kombinasi perlakuan yang terdiri dari: $\mathrm{L}_{0} \mathrm{D}_{0}, \mathrm{~L}_{0} \mathrm{D}_{1}, \mathrm{~L}_{0} \mathrm{D}_{2}, \mathrm{~L}_{1} \mathrm{D}_{0}, \mathrm{~L}_{1} \mathrm{D}_{1}, \mathrm{~L}_{1} \mathrm{D}_{2}, \mathrm{~L}_{2} \mathrm{D}_{0}, \mathrm{~L}_{2} \mathrm{D}_{1}, \mathrm{~L}_{2} \mathrm{D}_{2}$, masingmasing kombinasi terdiri dari 3ulangan total satuan percobaan 27 buah pot.

\subsection{Prosedur Penelitian}

Bahan baku biochar berupa sufmuti yang dikumpulkan setelah itu dipotong dengan ukuran $\pm 10 \mathrm{~cm}$ selanjutnya dikeringkan dengan cahaya matahari selama 24 jam. Sufmuti yang telah kering selanjutnya dibakar dengan menggunakan kontiki selama \pm 4 jam, dan didinginkan sebelum dihaluskan.

Proses pembuatan Biochar:

1. Menempatkan paralon ditengah-tengah kontiki pada lubang sarangan.

2. Sufmuti dimasukkan kedalam kontiki setengah bagian sambi dipadatkan dan meletakan arang ke dalam paralon 
3. Mengisi kontiki lagi dengan sufmuti sampai penuh.

4. Setelah kontiki terisi penuh mulut kontiki ditutup.

5. Sufmuti dibakar dari bawah pembakaran dapat dengan mudah berlangsung.

6. Sufmuti yang terbakar sedikit demi sedikit akan jatuh kebawah sambil dibolak balik menjadi arang sufmuti.

7. Arang sufmuti yang telah berwarna hitam dikeluarkan.

8. Arang sufmuti tersebut disiram dengan air bersih supaya arang tersebut tidak menjadi abu.

9. Arang sufmuti tersebut ditumbuk sampai halus dan diayak, kemudian dimasukkan kedalam karung dan siap untuk digunakan.

Bahan pembuatan teh kompos berbahan dasar lamtoro (Leucaena leucocephala) dan ekskreta ayam.

Cara Pembuatannya

1. Siapkan bahan yang akan digunakan untuk pembuatan pupuk kompos seperti ekskreta ayam, lamtoro (cacah), $\mathrm{EM}_{4}$, dan seng atau bahan lain untuk penutup.

2. Kemudian menyiapkan ekskreta ayam yang digunakan adalah $80 \mathrm{~kg}$, dan lamtoro sebanyak $20 \mathrm{~kg}$.

3. Campurkan ekskreta ayam, dan daun lamtoro dicampur secara manual sampai terlihat merata.

4. Kemudian melarutkan $160 \mathrm{ml} \mathrm{EM}_{4}$ kedalam 7 liter air, kemudian percikkan larutan tersebut ke campuran bahan-bahan yang sudah dicampur sebelumnya secara perlahan pada bagian permukaannya.

5. Selanjutnya bahan-bahan yang telah dicampur ditutup dengan menggunakan karung dan seng dengan rapat sehingga menciptakan suasana anaerob.

6. Pengomposan membutuhkan waktu 21 hari yang ditandai dengan suhu panas dipermukaan bakal kompos. Selama proses ini, dapat dilakukan pengadukan setiap 3 hari sekali untuk membantu proses aerasi

7. Tanda pengomposan sudah selesai adalah saat suhunya tidak tinggi lagi. Pupuk kompos siap untuk diaplikasikan.

Media tanam yang digunakan berupa tanah coklat jenis entisol yang telah diayak, media tiap polibag ditempatkan sebanyak $5 \mathrm{~kg}$ tanah dan dicampur dengan biochar sesuai perlakuan. Media tanam yang telah dibuat selanjutnya disiram dengan air sebanyak 2 liter dan diinkubasi selama 1 minggu sebelum ditanam.

Penanaman rumput odot dilakukan setelah masa inkubasi. Setiap polibag ditanami dengan 2 pols rumput odot. Setelah ditanam selanjutnya disiram menggunakan air sebanyak 2 liter pada setiap polibag lalu dibiarkan selama kurang lebih satu minggu sebelum diberi perlakuan.

Pemberian perlakuan biochar tanah dicampur dengan arang sufmuti sebanyak $100 \mathrm{~g}$ dan $300 \mathrm{~g}$. Kemudian diinkubasi selama 7hari. Sedangkan pemberian aplikasi teh kompos $150 \mathrm{ml}$ dan $300 \mathrm{ml}$ diberikan $7 \mathrm{hst}$ dan dilakukan pengulangan aplikasi pada minggu berikutnya sampai tanaman siap di panen.

Pemeliharaan meliputi penyiraman dan pembersihan pada gulma. Penyiraman air dilakukan pada tiap hari bilamana tidak terjadi hujan, sedangkan pembersihan terhadap gulma dilakukan dengan mencabut jenis tanaman lain yang hidup pada pot.

Pengambilan data dilakukan pada akhir masa penelitian dimana tajuk dari rumput odot dipanen selanjutnya dikeringkan menggunakan matahari selama 1 hari, selanjutnya dikeringkan menggunakan oven pada suhu $70^{\circ} \mathrm{C}$ selama 2 hari. Selanjutnya sampel di blender dan dimasukkan dalam plastik sampel dan siap untuk dianalisis laboratorium. Hasil analisis proksimat berupa bahan organik, serat kasar,bahan kering menjadi acuan dalam menyusun data hasil penyusunan.

\subsection{Prosedur Analisis Laboratorium}

\subsubsection{Kandungan Bahan Kering}

a. Cawan porselin dimasukan dalam oven bersuhu $105^{\circ} \mathrm{C}$ selama $1 \mathrm{jam}$.

b. Cawan porselin diambil dan didinginkan dalam eksikator selama 30 menit

c. Timbang cawan porselin dengan teliti (dicatat sebagai A g).

d. Timbangan yang digunakan adalah timbangan digital dan diketahui berat sampel dengan menset zero balans, yaitu setelah berat cawan aluminium diketahui dan dicatat, kemudian dizerokan sehingga penunjuk angka menjadi nol, sampel 1-2g langsung dimasukan ke dalam cawan, dan ditimbang beratnya (dicatat sebagai B g).

e. Cawan berisi sampel tadi dimasukan ke dalam oven dengan suhu $105^{\circ} \mathrm{C}$ sekurangnya 20 jam.

f. Selanjutnya cawan berisi sampel tersebut dikeluarkan dari oven, kemudian dimasukan dalam desikator selama 30 menit dan ditimbang (dicatat sebagai $\mathrm{Cg}$ ). Dihitung berat bahan kering degan rumus:

$$
\begin{array}{ll}
\text { Kadar Bahan Kering\% } & =(C-A) / B * 100 \% \\
\text { Kadar Air } \% & =100-\% \text { Bahan Kering }
\end{array}
$$

\subsubsection{Kandungan Bahan Organik}

Penentuan bahan-bahan organik dilakukan melalui tahap-tahap sebagai berikut:

a. Sampel dari analisa bahan kering dimasukan di dalam tanur listrik selama 3 jam pada suhu $600^{\circ} \mathrm{C}$.

b. Tanur dimatikan dan dibiarkan agak dingin kemudian tanur dibuka lalu sampel diambil dan dimasukan ke dalam desikator selama 30 menit, kemudian di timbang (g). Rumus yang digunakan adalah:

$$
\begin{gathered}
\text { Kadar abu }=\frac{d-a}{b-a} \times 100 \% \\
\text { Bahan organik }=\frac{100 \%-\text { Kadar } a b u}{100} \times B K \\
\mathrm{BO}=\% \mathrm{BO} \times \mathrm{BK}
\end{gathered}
$$

Keterangan:

$$
\begin{aligned}
& \mathrm{a}=\text { Berat cawan kosong }(\mathrm{g}) \\
& \mathrm{b}=\text { Berat cawan }+ \text { sampel sebelum di oven }(\mathrm{g}) \\
& \mathrm{d}=\text { Berat cawan }+ \text { sampel setelah di tanur }(\mathrm{g})
\end{aligned}
$$

\subsubsection{Kandungan Serat Kasar}

Penentuan serat kasar dilakukan melalui tahap-tahap sebagai berikut:

a) Dilakukan penimbangan bahan sampel yang telah dikeringkan dan dihaluskan sebanyak $5 \mathrm{~g}(\mathrm{X})$

b) Sampel dimasukan ke dalam gelas piala $500 \mathrm{~mL} \mathrm{H}_{2} \mathrm{SO}_{4}$ dan di masak hingga mendidih selama 30 menit.

c) Cairan di saring menggunakan kertas saring yang beratnya telah diketahui (a)

d) Pengeringan dilakukan di dalam labu penyisap yang dihubungkan dengan pompa vakum atau pancar air di cuci berturut-turut dengan:

1) $50 \mathrm{~mL}$ air panas

2) $50 \mathrm{~mL} \mathrm{H}_{2} \mathrm{SO}_{4}$

3) $25 \mathrm{~mL}$ acceton

e) Kertas saring dan isinya dimasukan ke dalam cawan porslen dan dikeringkan selama 1 jam pada oven dengan suhu $110^{\circ} \mathrm{C}$

f) Kertas saring didinginkan dalam eksikator dan ditimbang (Y)

g) Kemudian dipijarkan, didinginkan dan ditimbang (Z)

Rumus:

$$
\text { Kadar serat kasar }=\frac{Y-Z-a}{x} \times 100 \%
$$

Keterangan:

$$
\begin{aligned}
& \mathrm{Y}=\text { Berat kertas saring setelah didinginkan dalam eksikator } \\
& (\mathrm{g}) \\
& \mathrm{Z}=\text { Berat kertas saring setelah dipijarkan dan ditimbang }(\mathrm{g}) \\
& \mathrm{a}=\text { Berat awal kertas saring }(\mathrm{g}) \\
& \mathrm{X}=\text { Berat sampel yang digunakan }(\mathrm{g})
\end{aligned}
$$

\begin{tabular}{|c|c|c|c|c|c|}
\hline \multirow{2}{*}{$\begin{array}{l}\text { Level Biochar } \\
\text { (L) }\end{array}$} & \multirow{2}{*}{ Ulangan } & \multicolumn{3}{|c|}{ Dosis Teh Kompos (D) } & \multirow[t]{2}{*}{ Total Rataan } \\
\hline & & Kontrol & $150 \mathrm{ml}$ & $300 \mathrm{ml}$ & \\
\hline \multirow{3}{*}{ Kontrol } & 1 & 94.24 & 93.75 & 93.62 & \multirow{3}{*}{$93.64^{\mathrm{b}}$} \\
\hline & 2 & 93.99 & 94.13 & 94.11 & \\
\hline & 3 & 93.11 & 92.94 & 92.86 & \\
\hline \multicolumn{2}{|c|}{ Rataan } & 93.78 & 93.61 & 93.53 & $(-)$ \\
\hline \multirow{3}{*}{$\mathrm{L}-(100 \mathrm{~g})$} & 1 & 94.03 & 94.54 & 94.57 & \multirow{3}{*}{$94.16^{\mathrm{ab}}$} \\
\hline & 2 & 94.69 & 94.25 & 94.89 & \\
\hline & 3 & 93.36 & 93.39 & 93.73 & \\
\hline \multicolumn{2}{|c|}{ Rataan } & 94.03 & 94.06 & 94.39 & $(-)$ \\
\hline \multirow{3}{*}{ L-(200 g) } & 1 & 94.84 & 94.81 & 95.22 & \multirow{3}{*}{$94.66^{\mathrm{a}}$} \\
\hline & 2 & 94.37 & 95.49 & 95.23 & \\
\hline & 3 & 93.60 & 94.15 & 94.22 & \\
\hline \multicolumn{2}{|c|}{ Rataan } & 94.27 & 94.82 & 94.89 & $(-)$ \\
\hline \multicolumn{2}{|c|}{ Total Rataan } & 94.03 & 94.16 & 94.27 & \\
\hline
\end{tabular}

\subsubsection{Analisis Data}

Semua data yang dikumpulkan dianalisis dengan menggunakan analisis sidik ragam (ANOVA) sesuai dengan rancangan yang digunakan yaitu Rancangan Acak Lengkap (RAL) Pola Faktorial. Kemudian dilanjutkan uji lanjut Duncan untuk melihat perbedaan antar perlakuan. Analisis data menggunakan Software SAS versi 9.

\section{HASIL DAN PEMBAHASAN}

Bahan Kering (BK) adalah bahan yang terkandung di dalam bahan pakan setelah dihilangkan airnya. Hasil analisis detail kandungan bahan kering (BK) rumput odot seperti terlihat pada Tabel 1.

Tabel 1. Rataan kandungan Bahan Kering (\%)

Keterangan: Angka yang diikuti huruf berbeda pada grafik diatas menunjukan berbeda nyata pada uji $\alpha 0.05$

Hasil analisis sidik ragam menunjukan bahwa tidak terjadi interaksi antara faktor level biochar dan dosis teh kompos terhadap kandungan 
bahan kering yang dihasilkan. Kandungan bahan kering rumput odot lebih dipengaruhi oleh faktor level biochar sedangkan faktor dosis teh kompos berpengaruh tidak nyata $(\mathrm{P}>0.05)$.

Tabel 1 menunjukkan bahwasecara numerik perlakuan level biochar 200gram (L2) mampu menghasilkan kandungan bahan kering tertinggi yaitu sebesar $94,66 \%$ yang disebabkan karena pemberian biochar mampu menyediakan kandungan $\mathrm{N}$ bagi tanaman yang bermanfaat dalam pertumbuhan rumput odot. Menurut Laird (2008) aplikasi biochar kedalam tanah berpengaruh terhadap meningkatnya kesuburan tanah. Hal ini dimungkinkan karena biochar yang berpori menjadi tempat berkembangnya mikroorganisme tanah yang berguna untuk mendaur ulang bahan organik didalam tanah dan tingginya daya tahan biochar dalam tanah yaitu bisa mencapai 1000 tahun untuk terurai, selanjutnya dapat memicu bertambahnya populasi organisme tanah sehingga ketersediaan unsur hara dapat terus dipertahankan dalam jangka waktu yang lama. Meningkatnya jumlah organisme tanah terutama mikroorganisme penambat $\mathrm{N}$ dapat menunjang pertumbuhan sehingga berkorelasi dengan kandungan bahan kering yang dihasilkan.

Kombinasi penggunaan level biochar sebanyak 200gram dan dosis teh kompos $300 \mathrm{ml} / \operatorname{tanaman}\left(\mathrm{L}_{2} \mathrm{D}_{2}\right)$ memberikan hasil produksi bahan kering tertinggi sebesar $94,89 \%$. Tingginya produksi bahan kering rumput odot yang mendapat perlakuan $\mathrm{L}_{2} \mathrm{D}_{2}$, disebabkan karena kombinasi level biochar 200gram dan dosis teh kompos 300ml/tanaman mampu menyediakan unsur hara yang maksimal sehingga memberikan kontribusi terhadap produksi secara keseluruhan yang berdampak terhadap peningkatan produksi bahan kering rumput odot. Peran biochar dalam tanah dapat berfungsi sebagai pembenah tanah, meningkatkan pertumbuhan tanaman, dengan menambah sejumlah nutrisi yang berguna sehingga meningkatkan sifat kimia, fisika dan biologi tanah. Sedangkan pemberian teh kompos ekskreta ayam meningkatkan ketersediaan nitrogen tanah sehingga mampu mencukupi kebutuhan tanaman (Pangaribuan et al., 2012). Pemberian level biochar dan teh kompos yang tinggi akan meningkatkan kelarutan bahan unsur hara yang dibutuhkan oleh tanaman. Makin tinggi tingkat kelarutan unsur hara, maka makin banyak unsur hara yang dimanfaatkan oleh tanaman untuk berproduksi, sehingga dapat meningkatkan produksi bahan segar dan pada gilirannya akan meningkatkan pula produksi bahan kering. Hal ini sesuai dengan yang dilaporkan oleh Dapa, (2016) dalam hasil penelitiannya bahwa produksi rumput odot sangat dipengaruhi pemupukan, dengan hasil produksi segar rumput Odot (Pennisetum purpureum Cv. Mott) sebesar $8,29 \mathrm{~kg} / \mathrm{m}^{2}$ atau 82,9 ton/ha/45 hari dengan menggunakan biourin. Pujiati, (2011), menyatakan bahwa pemupukan dapat memberikan produksi bobot segar suatu tanaman menjadi lebih tinggi. Hakim et al. (2007) menyatakan bahwa pemberian unsur hara yang lengkap pada tanaman memberikan pengaruh produktifitas dan pertumbuhan suatu tanaman.

\subsection{Bahan Organik}

Bahan organik merupakan penimbunan dari sisa-sisa tanaman dan binatang yang sebagian telah mengalami pelapukan dan pembentukan kembali. Bahan organik demikian berasal dalam pelapukan aktif dan menjadi mangsa serangan jasad mikro. Sebagai akibatnya bahan tersebut berubah terus dan tidak mantap sehingga harus selalu diperbaharui melalui sisa-sisa tanaman (Nugroho 2012). Hasil analisis kandungan bahan organik (BO) rumput odot terlihat pada Tabel 2.

Tabel 2 Pengaruh Perlakuanterhadap kandungan Bahan Organik (\%).

\begin{tabular}{|c|c|c|c|c|c|}
\hline \multirow{2}{*}{$\begin{array}{l}\text { Level Biochar } \\
\text { (L) }\end{array}$} & \multirow{2}{*}{ Ulangan } & \multicolumn{3}{|c|}{ Dosis Teh Kompos (D) } & \multirow[t]{2}{*}{ Total Rataar } \\
\hline & & Kontrol & $150 \mathrm{ml}$ & $300 \mathrm{ml}$ & \\
\hline \multirow{3}{*}{ Kontrol } & 1 & 78.83 & $\overline{77.79}$ & 80.31 & \multirow{3}{*}{78.24} \\
\hline & 2 & 75.88 & 78.34 & 80.28 & \\
\hline & 3 & 76.35 & 77.06 & 79.29 & \\
\hline \multicolumn{2}{|c|}{ Rata-rata } & 77.02 & 77.73 & 79.96 & $(-)$ \\
\hline \multirow{3}{*}{ L-(100 g) } & 1 & 76.62 & 77.86 & 79.89 & \multirow{3}{*}{77.50} \\
\hline & 2 & 76.47 & 78.87 & 77.27 & \\
\hline & 3 & 75.54 & 77.36 & 77.58 & \\
\hline \multicolumn{2}{|c|}{ Rata-rata } & 76.21 & 78.03 & 78.25 & $(-)$ \\
\hline \multirow{3}{*}{ L-(200 g) } & 1 & 78.87 & 78.38 & 80.69 & \multirow{3}{*}{78.68} \\
\hline & 2 & 77.00 & 79.95 & 79.20 & \\
\hline & 3 & 76.94 & 78.16 & 78.95 & \\
\hline \multicolumn{2}{|c|}{ Rata-rata } & 77.60 & 78.83 & 79.61 & $(-)$ \\
\hline \multicolumn{2}{|c|}{ Total Rataan } & $76.94^{\mathrm{c}}$ & $78.20^{b}$ & $79.027^{\mathrm{a}}$ & \\
\hline
\end{tabular}

Keterangan: Angka yang diikuti huruf berbeda pada grafik diatas menunjukkan berbeda nyata pada uji $\alpha 0.05$

Hasil analisis sidik ragam menunjukan bahwa tidak terjadi interaksi antara faktor level biochar dan dosis teh kompos terhadap kandungan bahan organik yang dihasilkan. Kandungan bahan organik rumput odot lebih dipengaruhi oleh faktor dosis teh kompos sedangkan faktor level biochar berpengaruh tidak nyata $(\mathrm{P}>0.05)$. Pada tabel 2 menunjukan Dosis teh kompos $300 \mathrm{ml}\left(\mathrm{D}_{2}\right)$ mampu menghasilkan kandungan bahan organik tertinggi yaitu sebesar 78,24\% yang disebabkan karena dosis teh kompos memberikan peningkatan kesuburan tanaman yang seimbang dan meningkatan unsur hara tanah. Penggunaan dosis teh kompos mampu meyediakan habitat yang baik bagi mikroba tanah misalnya bakteri yang mampu membantu dalam perombakan unsur hara agar unsur hara tersebut dapat diserap oleh tanaman. Kombinasi penggunaan level biochar 200 gram dan dosis teh kompos $300 \mathrm{ml} /$ tanaman memberikan hasil produksi bahan organik tertinggi sebesar $79.96 \%\left(\mathrm{~L}_{0} \mathrm{D}_{2}\right)$. Perlakuan dosis teh kompos memberikan respon yang positif dan seimbang untuk kesuburan tanah. Hal ini dilihat dari umur pemotongan, pada dosis teh kompos $\mathrm{L}_{0} \mathrm{D}_{2}$ dan $\mathrm{L}_{2} \mathrm{D}_{2}$ yang semakin naik dan semakin turun dikarenakan pemberian air seringkali membatasi pertumbuhan dan perkembangan tanaman budidaya Respon tumbuhan terhadap kekurangan air dapat dilihat pada aktivitas metabolismenya, morfologinya, dan tingkat pertumbuhannya. Pertumbuhan sel merupakan fungsi tanaman yang paling sensitif terhadap kekurangan air. Kekurangan air akan mempengaruhi tugor sel sehingga akan mengurangi perkembangan sel, sintesis protein, dan sintesis dinding sel (Gardner et al., 1991).

Menurut Karieen, (2007) nitrogen merupakan unsur yang paling banyak terakumulasi dalam bahan organik karena merupakan unsur yang penting dalam sel mikroba yang terlibat dalam proses perombakan bahan organik tanah. Lebih lanjut dikatakan bahwa bahan organik dihasilkan oleh tanaman melalui proses fotosintesis sehingga unsur karbon merupakan penyusun utama dari bahan organik tersebut. Peningkatan kandungan bahan organik disebabkan karena kandungan abu atau bahan anorganik yang semakin menurun dan rendah. Sesuai pendapat Kartasapoetra, (1991) bahwa semakin lama daun tidak dipotong maka daun akan melakukan proses fotosintesis yang semakin lama sehingga dapat meningkatkan produksi gula sederhana yang mengakibatkan kandungan BO meningkat Bahan organik merupakan bahan-bahan yang dapat diperbarui, didaur ulang, dirombak oleh bakteri-bakteri tanah menjadi unsur yang dapat digunakan oleh tanaman tanpa mencemari tanah dan air.

\subsection{Serat Kasar}

Serat kasar merupakan bagian dari karbonhidrat dan didefinisikan sebagai fraksi yang tersisa setelah didigesti dengam larutan asam sulfat standar dan sodium hidrooksida pada kondisi yang terkontrol (Suparjo, 2010). Serat kasar merupakan sisa-sisa bahan makanan yang telah mengalami proses pemanasan dengan asam kuat dan basa kuat selama 30 menit yang di lakukan di laboratorium. Dengan proses seperti ini dapat merusak beberapa macam serat yang tidak dapat dicerna oleh manusia dan tidak dapat diketahui komposisi kimia tiap-tiap bahan yang membentuk dinding sel. Oleh karena itu jumlah kandungan serat kasar sebesar $80 \%$ untuk hemisellulosa, 50-90\% untuk lignin, dan 20-50\% untuk sellulosa (Piliang dan Djojosoebagio, 2002). Salah satu yang mempengaruhi peningkatan serat kasar adalah peningkatan kadar air suatu bahan makan pada lama penyimpanan yang dapat mempengaruhi pertumbuhan dan aktivitas mikroorganisme selama disimpan sehingga serat kasar pada saat penyimpanan mengalami penurunan. Hasil analisis laboratorium terhadap kandungan serat kasar (SK) rumput odot terlihat pada Tabel 3.

Tabel 3. Pengaruh Perlakuan terhadap kandungan Serat Kasar (\%)

\begin{tabular}{|c|c|c|c|c|c|}
\hline \multirow{2}{*}{$\begin{array}{l}\text { Level Biochar } \\
\text { (L) }\end{array}$} & \multirow{2}{*}{ Ulangan } & \multicolumn{3}{|c|}{ Dosis Teh Kompos (D) } & \multirow[t]{2}{*}{ Total Rataan } \\
\hline & & Kontrol & $150 \mathrm{ml}$ & $300 \mathrm{ml}$ & \\
\hline \multirow{3}{*}{ Kontrol } & 1 & 25.23 & 25.85 & 24.20 & \multirow{3}{*}{$24.69^{b}$} \\
\hline & 2 & 24.49 & 26.20 & 24.19 & \\
\hline & 3 & 23.86 & 25.02 & 23.19 & \\
\hline \multicolumn{2}{|c|}{ Rata-rata } & 24.53 & 25.69 & 23.86 & $(-)$ \\
\hline \multirow{3}{*}{$\mathrm{L}-(100 \mathrm{~g})$} & 1 & 25.58 & 26.16 & 25.24 & \multirow{3}{*}{$25.71^{\mathrm{a}}$} \\
\hline & 2 & 24.32 & 26.55 & 28.46 & \\
\hline & 3 & 23.95 & 25.36 & 25.85 & \\
\hline \multicolumn{2}{|c|}{ Rata-rata } & 24.62 & 26.02 & 26.51 & $(-)$ \\
\hline \multirow{3}{*}{ L-(200 g) } & 1 & 25.69 & 26.08 & 24.63 & \multirow{3}{*}{$24.39^{\mathrm{b}}$} \\
\hline & 2 & 24.39 & 24.05 & 23.52 & \\
\hline & 3 & 24.04 & 24.07 & 23.08 & \\
\hline \multicolumn{2}{|c|}{ Rata-rata } & 24.71 & 24.73 & 23.74 & $(-)$ \\
\hline \multicolumn{2}{|c|}{ Total Rataan } & 24.62 & 25.48 & 24.71 & \\
\hline
\end{tabular}

Hasil analisis sidik ragam menunjukan bahwa tidak terjadi interaksi antara faktor level biochar dan dosis teh kompos terhadap kandungan serat kasar yang dihasilkan. Kandungan serat kasar rumput odot lebih dipengaruhi oleh faktor level biochar sedangkan dosis teh kompos berpengaruh tidak nyata $(\mathrm{P}>0,05)$. Tabel 3 menunjukkan bahwa perlakuan level biochar 200 gram $\left(\mathrm{L}_{2}\right)$ mampu menghasilkan kandungan serat kasar tertinggi yaitu sebesar $24.39 \%$ yang disebabkan karena pemberian level biochar mampu meyediakan kandungan $\mathrm{N}$ bagi tanaman yang bermanfaat bagi pertumbuhan rumput odot.

Pada Tabel 3 menunjukkan bahwa nilai nutrien serat kasar pada rumput odot tertinggi dihasilkan pada perlakuan $\mathrm{L}_{1} \mathrm{D}_{2}(26,51 \%)$. Semakin rendah serat kasar, maka semakin tinggi kecernaan ransum, Semakin tinggi 
kandungan serat kasar pada suatu bahan pakan, maka kecernaan ransum semakin rendah artinya semakin rendah serat kasar semakin baik. Serat kasar adalah bagian dari pangan yang tidak dapat terhidrolisis oleh bahan bahan kimia yang digunakan intuk menentukan kadar serat kasar yaitu asam sulfat $\left(\mathrm{HSO}_{4}\right.$ 1,25\%) dan natrium hidroksida ( $\left.\mathrm{NaOH} 1,25 \%\right)$. Kandungan serat kasar cenderung meningkat sejalan dengan meningkatnya umur tanaman dan diturunkanya level pemupukan, diperkirakan karena unsur $\mathrm{N}$ dapat mempermudah akar untuk mengabsorbsi air dalam tanah, menyebabkan tanaman lebih banyak mengandung air sehingga dapat menghambat terjadinya lignifikasi pada bagian tanaman (Keraf et al., 2015). Serat kasar sangat penting dalam memenuhi kebutuhan zat makanan bagi ternak ruminansia (Anggorodi, 1984). Biochar mempunyai fungsi dapat membantu kelembaban dan kesuburan tanah. Selain itu aplikasi biochar meningkatkan nilai KTK sehingga penyerapan unsur hara dan penyimpanan air di dalam tanah lebih tinggi. Pada serat kasar level biochar mengalami peningkatan pada tiap aplikasi dimana aplikasi level biochar $100 \mathrm{~g}\left(\mathrm{~L}_{1}\right)$ paling tinggi yaitu $26 \%$. Teh kompos sebagai sumber hara terlarut untuk menambahkan atau mengoreksi defiensi unsur hara tanaman sangat efektif, dosis teh kompos pada grafik yang peningkatan semakin baik dikarenakan peyediaan hara yang lebih cepat dan siap diserap oleh tanaman baik melalui akar maupun daun. (Pant et al., 2009). Teh kompos makin meningkat pemanfaatannya terutama bagi pengembangan pertanian organik, karena fungsi gandanya baik sebagai penyedia hara.

\section{Kesimpulan}

Dari uraian hasil penelitian dapat disimpulkan sebagai berikut:

Pemberian level biochar dapat memberikan pengaruh nyata terhadap produksi bahan kering dan serat kasar yang dihasilkan, level biochar $200 \mathrm{~g}\left(\mathrm{~L}_{2}\right)$ menghasilkan produksi bahan kering tertinggi yaitu 94,65\% dan kandungan serat kasar yang rendah sebesar 24,39\%.

2. Pemberian dosis teh kompos memberikan pengaruh yang nyata terhadap bahan organik rumput odot. Dosis teh kompos 300ml/tanaman $\left(\mathrm{D}_{2}\right)$ memberikan hasil terhadap kandungan bahan organik rumput odot sebesar $79,27 \%$.

3. Tidak terjadi interaksi antara faktor pada semua variabel pengamatan.

\section{DAFTAR PUSTAKA}

Anggorodi. R. 2005. Ilmu Makanan Ternak Umum. Gajah Mada University Press Jogyakarta.

Anggorodi, R. 1984. Ilmu Makanan Ternak Umum. PT. Gramedia. Jakarta.

Bilbao, M., JJ Martinezdan A. Delgado, 2004. Evaluasi nitrat tanah sebagai predictor requierment nitrogen untuk bit gula ditanam di iklim meditteranean Argon. J. 96:18-25.

Damanik, J. 2009. Pengaruh Pupuk Hijau Kirinyuh (Chromolaena Odoratc L). Terhadap Pertumbuhan dan Produksi Jagung (Zea mays L.) Skripsi. Universitas Sumatera Utara Medan.

Dapa, Ds. S. U. N. 2016. Pengaruh Pemberian Pupuk Urea, Biourine dan Kombinasinya terhadap Tingkat Produktifitas Rumput Gajah Kate (Pennisetum purpureum $C v$. Mott) pada Setiap Umur Pemotongan. Universitas Warmadewa, Denpasar.

Djaja, W. 2008. Langkah Jitu Membuat Kompos dari Kotoran Ternak dan Sampah. Jakarta: PT. Agro Media Pustaka.

Despal, N. S., Suryahadi, D. Evvyernie., A. Sardiana., I. G. Permana, dan T. Toharmat. 2007. Nutrisi Ternak Perah. Departemen Ilmu Nutrisi dan Teknologi Pakan. Fakultas Peternakan. Institut Pertanian Bogor. Bogor.

Djuned, H. M dan Heni B. W. 2005. Pengaruh umur pemotongan Terhadap Kandungan Fraksi Serat Hijauan Mumbei(Morus Indica I. Var. Kanva-2)

Dwidjoseputro, D. 1984. Pengantar Fisiologis Tumbuhan. Penerbit PT. Gramedia Jakarta. pp.66-106.

Gani, A. 2009. Potensi Arang Hayati Biochar Sebagai Komponen Teknologi Perbaikan Produktivitas Lahan Pertanian. Iptek Tanaman Pangan .4:1. Balai Besar Penelitian Tanaman Padi. Sukamandi. Hal 33-48.

Gani, Anischan. 2009. Potensi Arang Hayati (Biochar) Sebagai Bahan Pembentuk Tanah. Iptek Tanaman Panganvol 4. No 1. Sukamandi. 33-44 hal.s

Gardner, F. P., Perace, R. B., dan Mitchell, R. L 1991. Fisiologi Tanaman Budidaya. Penerjemah: Susilo, H. Jakarta: UI Press.

Hakim, N., N. Yusuf, A. Lubis, G.N. Sutopo, D. Amin, G.B. Hong dan H.H. Bailey. 2007. Dasar-Dasar Ilmu Tanah. Universitas Lampung, Lampung.

Hanafiah, 2004. Dasar-dasar ilmu tanah. Rajagrafindo Persada. Jakarta.

Hartanto. 2008. Estimasi Konsumsi Bahan Kering, Protein Kasar, Total Digestible Nutriens dan Sisa Pakan Pada Sapi Peranakan Simmental.Agromedia 26(2).

Harwati, T. 2007. Pengaruh kekurangan air (Water Deficit) terhadap pertumbuhan dan perkembangan tanaman tembakau.Jurnal Inovasi Pertanian. 6(1):44-51.
Hunter. 2002. Fisiologi Nutrisi: Edisi Keempat. IPB Press: Bogor.

Hidayat, M. F. 2003. Pemanfaatan Asam Humat dan Omega pada Pemberian Pupuk NPK terhadap pertumbuhan Gmelina arborea Roxb yang Diinokulasi Cendawan Arbuskular (CMA). Tesis. Program Pancasarjana. Institut Pertanian Bogor.

Jackson, I. J., 1971. Climate, Water and Agriculture in the Tropics. Published in the United States of America by Longman Inc. New York.

Kastono, D. 2005. Tanggapan pertumbuhan dan hasil kedelai hitam terhadap penggunaan pupuk organic dan biopestisida gulma siam (Chromolaena odorata). Jurnal Ilmu Pertanian. (Vol. 1) 4-17

Keraf, F. K., Y. Nulik dan M. L. Mullik. 2015. Pengaruh pemupukan nitrogen dan umur tanaman terhadap produsksi dan kualitas rumput kume (Sorghumplumosum var. timorense). Jurnal Peternakan Indonesia 17:123-130.

Kouyoumjian RE, 2007. Comparison of Compost Tea And Biological Fungicides For Control Of Early Blight In Organic Heirloom Tomato Production. Tesis. Clemson University. Clemson.

Kozloski GV, Perottoni J, Sanchez LMB. 2005. Influence of regrowth age on dwarf elephant grass hay (Pennisetum purpureum Schum cv. Mott).

Lasamadi RD, Malalantang SS, Rustandi, Anis SD. 2013. Pertumbuhan dan Perkembangan Rumput Gajah dwarf (Pennisetum purpureum $c v$. Mott) yang diberi Pupuk Organik Hasik Fermentasi EM4. Jurnal Zootek,32 (5):158-171.

Lehmann, J. and M. Rondon. 2006. Bio-char Soil Management on Highly Weathered Soils in The Tropics. In: NUphoff (ed), Biological Approaches to Sustainable Soil Systems, Boca Raton, CRC Press. Taylor and Francis Group. pp.517-530.

Liang B. J. Lehman, D. S. 2011. Pengaruh Biochar dari Limbah Sagu Terhadap Pelindian Nitrogen di Lahan Kering Masam. 11:2.

Lingga dan Marsono, 2003. Petunjuk Penggunaan Pupuk Penebar swadaya, Jakarta.

Mansyur, S. Hardjosoewignyo dan L. Abdullah. 2004. Respon Rumput Brachiaria humudicola (Rendle) Schweick Terhadap Interval Pemotongan. Jurnal Ilmu Ternak, 4 (2): 57 - 61.

Maryam A, Anas DS, Juang GK. 2008. Pengaruh Jenis Pupuk Organik terhadap Pertumubuhan dan Hasil Panen Tanaman Sayuran di Dalam Nethouse. Makalah Seminar Departemen Agronomi dan Hortikultura Fakultas Pertanian Institut Pertanian Bogor 2008.

Maynard, L. A. Loosil, J. K. Hintz, H. F. and Warner, R. G., 2005. Animal nutrition.McGraw-Hill Book Cpmpany. New York, USA.

Mei Via Savitri, Herni Sudarwati, Hermanto. Pengaruh Umur Pemotongan Terhadap Produktifitas Gamal. Fakultas Peternakan Universitas Brawijaya.

Musnawar, E. I. 2009. Pupuk Organik Cair dan Padat, Pembuatan, Aplikasi. Penebar Swadaya: Jakarta.

Muhtaruddin. 2007.Kecernaan Pucuk Tebu Terolah secara In Vitro (The In Vitro Digestibility of Processed Sugarcane). Fakultas Pertanian Universitas Lampung, Bandar Lampung.

Murbandono, H, S. 1999. Membuat Kompos. Penebar Swadaya. IKAPI. Jakarta.

Nasir. 2007. Pengaruh Penggunaan Pupuk Bokasi Pada Pertumbuhan dan Produksi Padi Palawija dan Sayuran.

Nardi, S., F. Morari, A. Berti, M. Tosoni, dan L. Giardini, 2004. Soil organic matter properties after 40 years of different use of organic dan mineral fertilisers. Europ. J. Agronomy

Parker R. 2004. Plant science Revised. New York: Thomson Learning Inc

Prihmantoro, H. 2005. Memupuk Tanaman Sayur, Penebar Swadaya: Jakarta

Pujiati, E.D. 2011. Rumput dan legum sebagai hijauan makanan ternak. Graha Ilmu, Yogyakarta.

Radovich, T., N. V., Pant, A. 2011. Kualitas kompos. Dalam: Radovich \& Arancon (eds). Waktu minum teh di daerah tropis. Sekolah Tinggi Pertanian Tropis dan Sumber Daya Manusia. Universitas Hawaii di Manoa, Honolulu, Hawaii, AS.

Rangkuti, J. H. 2011. Produksi dan Kualita Susu Kambing Peranakan Etawah (PE) pada Kondisi Tata Laksana yang Berbeda. Departemen Ilmu Produksi dan Teknologi Peternakan. Fakultas Peternakan. Institut Pertanian Bogor.

Sembiring, M., \& Sinaga. (2003). Pengaruh Konsentrasi Asam Sulfat Terhadap Sifat Fisik dan Kimia Biochar dari Sludge Biogas pada Proses Aktivasi. In J. A. Sandra, Pengaruh Konsentrasi Asam Sulfat Terhadap Sifat Fisik dan Kimia Biochar dari Sludge Biogas pada Proses Aktivasi. Universitas Brawijaya: Malang.

Seseray D. Y., Santoso B dan Marlyn Nelce Lekitoo. 2013. Produksi Rumput Gajah (Pennisetum purpureum) yang Diberi Pupuk N, P dan K dengan Dosis 0, 50 dan 100\% pada Devoliasi Hari ke-45. Jurnal Sains Peternakan 11 (1): 49-55.

Setiawan, A. I. 2008. ManfaatKotoran Ternak, Penebar Swadaya: Jakarta.

Sirait J, Simanihuruk K, Hutasoit R. 2015. Palatabilitas dan kecernaan rumput gajah kerdil (pennisetum purpureum cv. Mott)

Susi. 2001. Analisis Dengan Bahan Kimia. Erlangga. Jakarta 
Suparjo, 2010.Analisis Bahan Pakan secara Kimiawi: Analisis Proksimat dan Analisis Serat.Jambi:Fakultas Peternakan

S, S., Lopez, C., Krull, E., \& Bol, R. 2009. Pengaruh Konsentrasi Asam Sulfat Terhadap Sifat Fisik dan Kimia Biochar dari Sludge Biogas pada Proses Aktivasi. Universitas Brawijaya: Malang.

Sutardi, Toha. 2009. Landasan Ilmu Nutrisi jilid 1. Fakultas Peternakan Institut Pertanian Bogor, Bogor.

Sylvia, E.W., 2004. The effect of compost extract on the yield of strawberries anseverity of Botrys cinera. J. suistainable Agric. 25

Suprapto, H, F, M. Suhartati dan T. Widiyastuti. 2013. Kecernaan serat kasar dan lemak kasar complete fed limbah dengan sumber protein berbeda pada kambing peranakam etawa. Jurnal ilmiah peternakan 1(3):938-946.

Suyitman, 2003. Diklat Agrostologi Fakultas Peternakan Universitas Andalas, Padang.

Tilman, D.A., Hatardi., H., Reksohadiprojo, S., Prawirokusumo, S. dan S. Lebdosoekojo. 2005. Ilmu Makanan Ternak Dasar. Gadjah Mada University Press. Fakultas Peternakan UGM. Yogyakarta.

Wahyu, 2004. Bahan Pakan Unggas Non Konvensional. Fakultas Peternakan Perikanan Universitas Muhamadiyah Malang. 